\title{
Important nesting habitats of olive ridley turtles Lepidochelys olivacea along the Andhra Pradesh coast of eastern India
}

\author{
Basudev Tripathy, Kartik Shanker and B. C. Choudhury
}

\begin{abstract}
Olive ridley turtles Lepidochelys olivacea nest along the east and west coasts of India, with major mass nesting beaches in the state of Orissa. The coast of Andhra Pradesh, the state immediately south of Orissa, has sporadic nesting of olive ridley turtles and is believed to form part of the migratory route of the turtles that nest in Orissa. A survey of nesting beaches and offshore waters of the Andhra Pradesh coast was carried out from November 2000 to April 2001. Preliminary interviews and secondary data were used to determine potential nesting beaches. During January-March 2001 intensive surveys of seven beaches and monthly surveys of the rest of the coast provided a lower bound of $c$. 4,000 nests along the Andhra Pradesh coast. Nesting densities were higher at beaches near river mouths, at 60-100 nests $\mathrm{km}^{-1}$ in northern and central Andhra Pradesh, and 15-20 nests km ${ }^{-1}$ in southern Andhra Pradesh. Sightings and incidental catch in experi-
\end{abstract}

mental trawls indicated the presence of olive ridley turtles in offshore waters. Fisheries related mortality is the major threat to the species, with nearly 1,000 dead turtles being washed ashore during January-March, but depredation of eggs by humans and feral animals was also widespread. Conservation efforts need to address these issues, and also the effects of coastal development and artificial illumination, especially at beaches that support relatively high densities of nesting olive ridley turtles.

Keywords Andhra Pradesh, bycatch, India, Lepidochelys olivacea, nest density, olive ridley turtle, Orissa.

This paper contains supplementary material that can only be found online at http://journals.cambridge.org

\section{Introduction}

Five species of marine turtles have been reported from Indian waters: the leatherback Dermochelys coriacea, hawksbill Eretmochelys imbricata, loggerhead Caretta caretta, green Chelonia mydas and olive ridley turtle Lepidochelys olivacea (Kar \& Bhaskar, 1982). All except the loggerhead turtle have been reported from the State of Andhra Pradesh on the east coast of India (Dutt, 1976, 1979; Biswas, 1982; Kar \& Bhaskar, 1982) but only olive ridley turtles have been reported to nest (Kar, 1983; Subba Rao et al., 1987). All five species are included in Schedule I of the Indian Wild Life (Protection) Act 1972, and are thereby accorded the highest degree of protection under the law; hunting of the turtles or damaging the eggs is strictly prohibited.

Olive ridley turtles are globally distributed and categorized as Endangered on the IUCN Red List (IUCN

Basudev Tripathy, Kartik Shanker ${ }^{1}$ (Corresponding author) and B. C. Choudhury Wildlife Institute of India, P.O. Box 18, Chandrabani, Dehradun 248001, India. Email: kartikshanker@vsnl.net

${ }^{1}$ Present address: Ashoka Trust for Research in Ecology and the Environment (ATREE) 659, 5th A Main Road, Hebbal, Bangalore 560024 India.

Received 30 April 2002. Revision requested 27 September 2002. Accepted 10 June 2003.
2002). Large nesting aggregations occur in Costa Rica and Mexico in the eastern Pacific and in the State of Orissa on the east coast of India (Pritchard, 1997). More than 100,000 turtles are believed to nest during mass nesting events or arribadas (spanish for arrival) at Gahirmatha, the northernmost rookery in Orissa, and $>10,000$ nest at other rookeries, mainly the mouth of Devi River and Rushikulya (Shanker et al., 2004). In recent years, the Orissa population has suffered severe fisheries related mortality with $>90,000$ dead adult turtles counted along the Orissa coast since 1994 (Pandav, 2001; B. Mohanty, pers. comm.).

Because Rushikulya, the southernmost mass nesting rookery in Orissa, is only $50 \mathrm{~km}$ from the Orissa-Andhra Pradesh border, the Andhra Pradesh coast could be an important nesting habitat for olive ridley turtles. The species is known to nest on the northern Andhra Pradesh coast (Raja Sekhar \& Subba Rao, 1993; Priyadarshini, 1998) and large numbers have been reported to travel through the offshore waters of the states of Tamil Nadu and Andhra Pradesh to and from the nesting beaches of Orissa (Kar, 1983; Raja Sekhar \& Subba Rao, 1993). However, little is known about the distribution and density of offshore aggregations or nesting along the coast, and there has been growing concern that, due to a rapid increase in the intensity of mechanized fishing along the Andhra Pradesh coast, significant mortality of 
turtles may be occurring during their breeding migrations. Although fisheries related mortality of marine turtles has been reported along this coast (Rao, 1984; Subba Rao et al., 1987; Raja Sekhar \& Subba Rao, 1993; Priyadarshini, 1998), there have been no systematic surveys of the entire coast. In this context, a survey of the Andhra Pradesh coast was conducted to assess the status of marine turtles and their nesting habitats. In this paper, we report the results of nesting and offshore surveys, assess the threats to this population and to its nesting habitats, and suggest conservation strategies based on our findings.

\section{Study area}

Andhra Pradesh is one of the largest maritime states in India (Fig. 1). The $980 \mathrm{~km}$ coastline extends from the Bahuda River mouth at the border with Orissa in the north to Pulicat, a large brackish water lagoon, in the south. The northern coastline is rocky with some sandy beaches, the central coast has river deltas and mangrove swamps, and the southern coast is largely sandy. The natural beach flora along this coastline comprises mostly psammophytes, particularly Ipomea pes-caprae, Spinifex littoreus and Launea sarmentosa. There are also patches of mangroves in the Godavari and Krishna deltaic systems, and degraded mangroves occur at a few other sites. However the dominant flora along the coast are palmyra Borassus flabellifer and Casuarina litorea plantations on the beach, mostly established by the state Forest Department as barriers against cyclones. Cashew Anacardium occidentale and coconut Cocos nucifera have also been planted in some areas.

Andhra Pradesh has nine coastal districts with 453 fishing villages and 280 landing centres; in 1998 the population of fishers was 0.87 million, with 8,642 mechanized boats, 3,269 motorized craft (boats fitted with outboard motors for gill-net operations) and 54,000 non-mechanized boats (traditional craft) in coastal Andhra Pradesh (Anon., 1999). Of the total marine fish catch, $32 \%$ is from trawl nets, $24 \%$ from non-mechanized drift gillnets, $14 \%$ from bottom set gillnets, $13 \%$ by shore seine nets and the remainder by boat seine nets, driftnets, hooks and lines and other gear (Alagaraja et al., 1987).

\section{Material and methods}

Based on broad topographical differences, the entire coast was divided into three zones, i.e. northern, central and southern Andhra Pradesh (Fig. 1). Each zone was divided into sectors based on physiographic features such as river mouths, bays and estuaries. The survey was conducted in three phases: a pre-nesting survey, an offshore survey and a nesting survey. During the pre-nesting survey of May-September 2000 one coastal village or fish landing centre was visited per $20 \mathrm{~km}$ of coastline, covering all 10 sectors. Information was collected from 100 fishers,

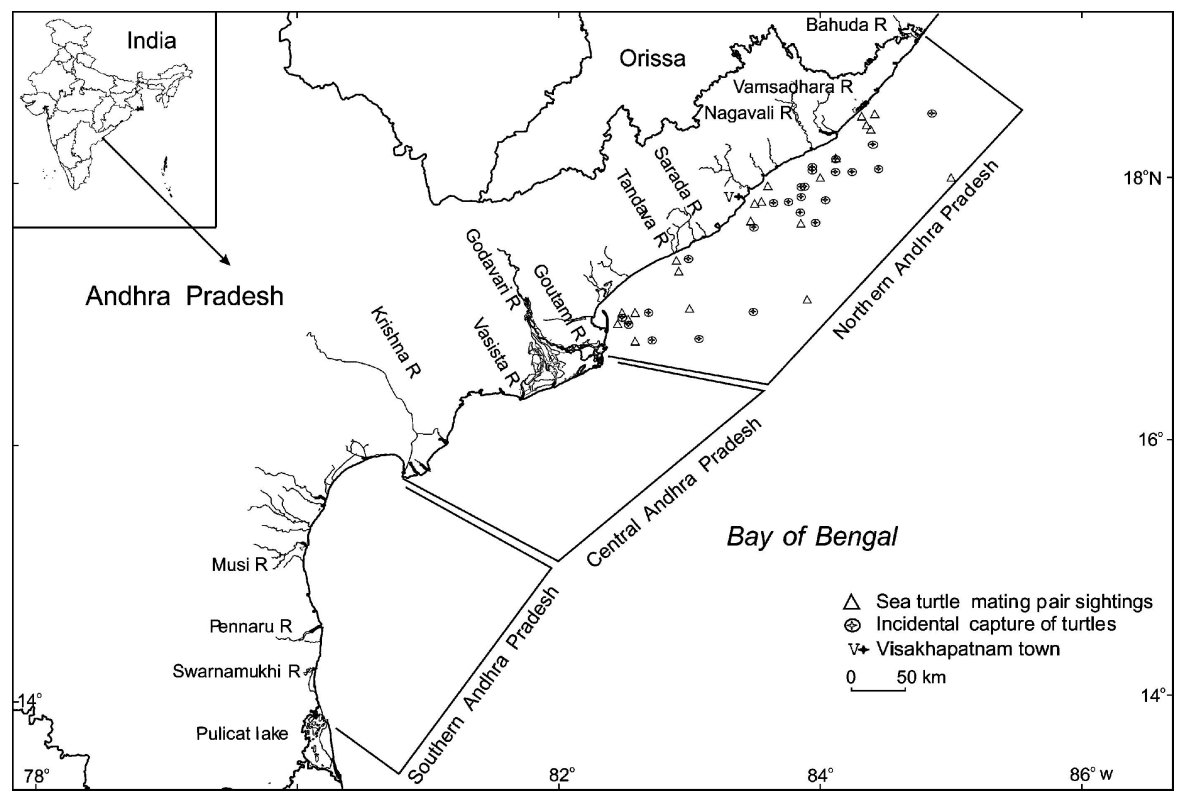

Fig. 1 The coast of Andhra Pradesh in eastern India. For the survey the coast was divided into northern, central and southern zones, and these were further subdivided into sectors, based mainly on the position of river mouths (see Table 3). Visual sightings of olive ridley mating pairs during offshore surveys and incidental capture during experimental trawls are also indicated. 
18 coastal Forest Department offices and 32 state Fisheries offices using questionnaire interviews (Tambiah, 1999; Appendix 1). Beach characteristics (topography, lighting, plantations and human habitation close to the beach) were evaluated subjectively.

The offshore survey was conducted on board the Fishery Survey of India's Matsya Darshini, a 37 m trawler designed for bottom trawling, with instruments for depth measurement. Two 2-week cruises were made, one each in November and December 2000. Each survey covered 350 nautical miles between the Orissa-Andhra Pradesh border and the mouth of the Krishna River. A total of 30 and 32 trawls, conducted 5-20 km offshore, each for $90 \mathrm{~min}$, were conducted on each survey at depths of 30-60 m. As effort was equal, catch per unit effort (CPUE) was calculated as the number of turtles captured per trawl. Locations of sightings of single turtles and mating pairs were recorded with a Global Positioning System.

The nesting survey was carried out in two parts: intensive surveys of seven beaches and monthly surveys of the rest of the coast. Nesting in Orissa to the north and Tamil Nadu to the south is primarily between January and March, with very low levels of nesting in December and April (Shanker, 1995; Pandav et al., 1998). During November-December 2000 and April 2001 short surveys were conducted to verify the beginning and end of the nesting season. During the monthly surveys a total of 723,361 , and $608 \mathrm{~km}$ were surveyed by motorcycle and on foot during January, February and March 2001, respectively. Because of logistic constraints the entire coast was not surveyed, and the number of nests was therefore interpolated within each sector where the entire sector was not surveyed, and within each zone when sectors were incompletely surveyed. Nesting crawls and depredated nests were counted to evaluate nesting densities. Because locations were visited monthly and only fresh crawls were counted, it is unlikely that crawls were recounted. However, since these were not daily counts, the nesting figures may be underestimates of total nesting and were therefore considered only as a relative index for each zone.

Olive Ridley turtles are believed to prefer nesting sites near river mouths (Pritchard \& Mortimer, 1999) and as mass nesting sites of ridley turtles in Orissa are known to be adjacent to river mouths (Pandav et al., 1998), six of the seven intensive surveys were therefore on such beaches. All river mouth beaches were first assessed for suitability for nesting based on physiography and degree of nearby development (i.e. rocky beaches or beaches with major townships nearby were considered unsuitable; Appendix 2). For three of these intensive surveys $28 \mathrm{~km}$ of coastline between the rivers Vamsadhara and Nagavali (Fig. 1) in northern Andhra Pradesh was divided into three segments, two adjacent to river mouths, and one between the towns of Bandarvanipeta and Kundavanipeta, and each was surveyed with a variable intensity of 6-23 days per month. The total number of nests per month was extrapolated from those of the days surveyed. Four further beaches, all adjacent to river mouths, were selected on the basis of the preliminary survey and patrolled daily; only fresh crawls and freshly depredated nests were counted, and the results therefore represent the total nesting during these months.

Stranded dead turtles were counted during the monthly surveys. Sex was determined by the presence of a long tail and strongly curved claw on the fore flipper in males. Curved carapace length was measured from the anterior point at the midline (nuchal scute) to the posterior tip of the supracaudal. Curved carapace width was measured at the widest part of the shell.

Potential nesting along the entire coast of Andhra Pradesh was estimated from the results of the intensive nesting surveys. Nesting was estimated separately for the beaches adjacent to river mouths and for the rest of the coast. Average nest density for river-mouth beaches was calculated from the intensive surveys of the six rivermouth beaches. Total nesting was calculated as: number of river mouth beaches suitable for nesting * average length of beach * average nest density of river mouth beaches. To calculate the total nesting for the other beaches the relative nest densities in the three zones (north, central and south) were first of all calculated from the extensive surveys. The nest density for beaches in the northern zone was then estimated from the intensive survey of the one beach (within this zone) that was not on a river mouth. For the central and southern zones nest densities were calculated from the relative densities. Total nesting was estimated based on available beach length in each of the zones.

Non parametric tests (Mann Whitney U test, SPSS Version 8.0) were used to test differences in sizes between male and female turtles and dead turtles and turtles captured in offshore trawls.

\section{Results}

\section{Pre-nesting survey}

All interviewees reported nesting by olive ridley turtles (Table 1). A slightly larger percentage of Fisheries Department offices $(21.9 \%)$ and fishers $(20 \%)$ reported the presence of other species (leatherback, hawksbill and green turtles) compared to Forest Department offices (11.1\%). Both Departments reported the consumption of eggs. However, while $38.9 \%$ of Forest Department offices reported the consumption of meat, $78.1 \%$ of Fisheries offices reported this. One third of Forest Department offices 
Table 1 Results of interviews (Appendix 1) with coastal Forest Department offices, state Fisheries Department offices and fishers (by zone, see Fig. 1, and the total) along the Andhra Pradesh coast. All values are the percentage of affirmative answers to each question. (DNC, did not comment/did not know).

\begin{tabular}{|c|c|c|c|c|c|c|}
\hline \multirow[b]{2}{*}{ Question } & \multirow[b]{2}{*}{$\begin{array}{l}\text { Forest } \\
\text { Department } \\
(n=18)\end{array}$} & \multirow[b]{2}{*}{$\begin{array}{l}\text { Fisheries } \\
\text { Department } \\
(n=32)\end{array}$} & \multicolumn{4}{|l|}{ Fishers } \\
\hline & & & $\begin{array}{l}\text { Northern } \\
\text { zone }(n=46)\end{array}$ & $\begin{array}{l}\text { Central } \\
\text { zone }(n=26)\end{array}$ & $\begin{array}{l}\text { Southern } \\
\text { zone }(n=28)\end{array}$ & $\begin{array}{l}\text { Total } \\
(n=100)\end{array}$ \\
\hline Olive ridley nesting? & 94.4 & 100.0 & 100.0 & 100.0 & 100.0 & 100.0 \\
\hline$>50$ nests per season? & $\mathrm{DNC}$ & DNC & 78.3 & 84.6 & 64.3 & 76.0 \\
\hline Decline in nesting? & DNC & $\mathrm{DNC}$ & 97.8 & 88.5 & 85.7 & 92.0 \\
\hline Other turtle species? & 11.1 & 21.9 & 28.3 & 15.4 & 10.7 & 20.0 \\
\hline Fisheries related mortality? & 100.0 & 100.0 & 100.0 & 100.0 & 100.0 & 100.0 \\
\hline Mortality due to mechanized fishing? & $\mathrm{DNC}$ & 65.7 & 93.5 & 80.7 & 75.0 & 85.0 \\
\hline \multicolumn{7}{|l|}{ Seasonality of bycatch } \\
\hline Dec.-Jan. & $\mathrm{DNC}$ & $\mathrm{DNC}$ & 47.8 & 7.7 & 17.9 & 29.0 \\
\hline Jan.-Feb. & $\mathrm{DNC}$ & $\mathrm{DNC}$ & 89.1 & 96.2 & 89.3 & 91.0 \\
\hline Feb.-Mar. & DNC & $\mathrm{DNC}$ & 47.8 & 34.6 & 50.0 & 45.0 \\
\hline Mar.-Apr. & $\mathrm{DNC}$ & $\mathrm{DNC}$ & 10.9 & 3.8 & 7.1 & 8.0 \\
\hline$>10$ dead turtles per season? & DNC & DNC & 65.2 & 53.8 & 21.4 & 50.0 \\
\hline Consumption of eggs? & 88.9 & 100.0 & $\mathrm{DNC}$ & DNC & DNC & DNC \\
\hline Consumption of meat? & 38.9 & 78.1 & $\mathrm{DNC}$ & DNC & DNC & DNC \\
\hline Forest Department protection? & 33.3 & 0.0 & 0.0 & 11.5 & 0.0 & 3.0 \\
\hline
\end{tabular}

reported measures of protection by their Department, but Fisheries Department offices and fishers reported that there was no and little protection, respectively.

Nearly $30 \%$ of the fishers in northern Andhra Pradesh and $10-15 \%$ in other zones reported the presence of species other than olive ridley turtles (Table 1), namely, leatherback, green and hawksbill turtles. The fishers identified the species from photographs and had local names for each species. Olive ridley turtles are known as punuku tambelu ( punuku=hole, tambelu=turtle) for the small pore near the rear margin of each of the four infra-marginal scutes in their plastron. The hawksbill turtle is identified from its beak and is known as chilaka tambelu (chilaka=parakeet). The Green turtle is called pedda tambelu (pedda=large) and the leatherback is known as doni tambelu (doni=bullock cart wheel), as an indication of its size. The occurrence of loggerhead turtles could not be confirmed.

Seventy-six percent of fishers reported nesting intensities of $>50$ nests per season; $92 \%$ reported a decline in the last decade and $85 \%$ reported that they thought this was due to trawling-related mortality (Table 1). All zones reported high mortalities in January-February (91\%), moderate levels in February-March (45\%) and low levels in March-April (8\%). $92 \%$ of fishers said that marine turtles were neither beneficial nor harmful, while the other $8 \%$ said they were negatively affected by the entanglement of turtles in their nets. The fishers identified the breeding and nesting seasons of olive ridley turtles as November-March.
In Hindu mythology marine turtles are worshipped as an incarnation (kurma) of one of the Hindu gods, and hence most fishing communities along the coast do not consume turtle meat. In northern Andhra Pradesh there is a caste named after the turtle (kurma kulam) and there are two temples devoted to turtles, the only ones of their kind in India. However, a few fishing communities collect turtle eggs for local consumption and sale at Rs 0.50 (1 US cent) each. In a few fishing villages in northern Andhra Pradesh an extract of marine turtle liver and bile is used to treat pregnancy related and rheumatic diseases.

\section{Offshore surveys}

A total of 27 mating pairs and 25 single turtles were sighted within $5-10 \mathrm{~km}$ of the coast during the offshore survey (Fig. 1). During this time $>100$ trawlers (an exact count was not made) were observed fishing within $5-10 \mathrm{~km}$ of the coast, where mechanized fishing is illegal. We caught and released a total of 32 and 30 olive ridley turtles in November and December, respectively, with an average of one turtle per trawl. The average number of turtles caught during trawls was 0.79 at $30-40 \mathrm{~m}(n=14), 1.03$ at $40-50 \mathrm{~m}(n=32), 1.2$ at $50-70 \mathrm{~m}$ $(n=10)$, and 0.5 at depths $>70 \mathrm{~m}(n=6)$. The November catch of marine turtles in trawl nets was dominated by males $(97 \%)$ whereas all turtles caught in December were females. There was little if any difference in the mean sizes of male and female turtles (Table 2). 
Table 2 Summary of size measurements of male and female olive ridley turtles captured and released during offshore trawls, and dead turtles stranded on beaches.

\begin{tabular}{|c|c|c|c|c|c|}
\hline \multirow[b]{2}{*}{ Location } & \multirow[b]{2}{*}{$\operatorname{Sex}(n)$} & \multicolumn{2}{|c|}{ Curved carapace length } & \multicolumn{2}{|c|}{ Curved carapace width } \\
\hline & & Mean (SE) & Range & Mean (SE) & Range \\
\hline \multirow[t]{2}{*}{ Offshore } & Males (15) & $66.3(3.8)$ & $57.0-70.0$ & $63.8(5.4)$ & $51.0-69.0$ \\
\hline & Females (14) & $67.3(4.0)$ & $57.0-71.5$ & $65.7(3.7)$ & $51.0-70.5$ \\
\hline \multirow[t]{3}{*}{ Dead on beach } & Males (41) & $68.4(3.4)$ & $58.2-78.0$ & $65.5(5.0)$ & $48.3-75.5$ \\
\hline & Females (35) & $67.4(6.7)$ & $44.4-78.0$ & $64.5(7.0)$ & $42.2-75.4$ \\
\hline & Unknown (35) & $68.2(4.2)$ & $56.5-76.3$ & $65.8(4.9)$ & $48.3-72.5$ \\
\hline
\end{tabular}

\section{Nesting survey}

The results of the extensive survey indicated higher intensity of nesting in northern $\left(2.7\right.$ nests $\left.\mathrm{km}^{-1}\right)$ and central ( 3.8 nest $\mathrm{km}^{-1}$ ) than southern Andhra Pradesh (0.96 nests $\mathrm{km}^{-1}$ ) (Table 3). These represent counts from monthly surveys for January-March 2001 and are underestimates of the total nesting.

The intensive surveys of the single beach, in northern Andhra Pradesh, that was not adjacent to a river mouth (Bandarvanipeta-Kundavanipeta) indicated a nest density of 13 nests $\mathrm{km}^{-1}$ (Table 4). Intensive surveys of the six river mouth beaches indicated nest densities of 60-114 nests $\mathrm{km}^{-1}$ in northern and central Andhra Pradesh and 15-18 nests $\mathrm{km}^{-1}$ in southern Andhra Pradesh (Tables 4 \& 5).

Short surveys carried out in November, December and April indicated that nesting during these months was negligible. The intensive surveys indicated maximum nesting in February and March (Tables 3-5), although peaks at different sites were not synchronous (Fig. 2). Almost all nests of olive ridley turtles along the Andhra Pradesh coast were depredated. Dogs Canis familiaris were frequently observed depredating nests, and jackals Canis aureus and hyenas Hyeana hyaena were also sighted along the coast and are known to depredate turtle nests.

\section{Potential nesting}

Although the intensive surveys in Andhra Pradesh (Tables 4 \& 5) and nesting distributions in Orissa (Pandav et al., 1998) indicated that nesting densities were generally higher near river mouths, no data is available to determine the relationship between nest density and distance from a river mouth. However, based on the fact that mass nesting beaches occur within $c .5 \mathrm{~km}$ of river mouths in Orissa (Pandav et al., 1998), and on results from the intensive survey (Tables 4 \& 5), we assumed a conservative length of $3 \mathrm{~km}$ for high density nesting at river-mouth beaches. There are 18 rivers in northern

Table 3 Number of olive ridley turtles nesting in the 10 sectors of the Andhra Pradesh coast (Fig. 1). Length indicates the extent of suitable nesting beaches within each sector. Nesting numbers represent the counts from single surveys only and hence may be underestimates of total nesting in each sector. Nesting was extrapolated within each sector when the entire sector was not surveyed, and within each zone when sectors within the zone were incompletely surveyed (in italics, with distances surveyed in parentheses).

\begin{tabular}{|c|c|c|c|c|c|c|}
\hline \multirow[b]{2}{*}{ Zone } & \multirow[b]{2}{*}{ Sector } & \multirow[b]{2}{*}{ Length $(\mathrm{km})$} & \multicolumn{4}{|c|}{ Number nesting } \\
\hline & & & Jan. & Feb. & Mar. & Total \\
\hline \multirow[t]{5}{*}{ Northern } & Bahuda-Vamsadhara & 100 & 2 & 270 & 111 & \\
\hline & Vamsadhara-Nagavali & 28 & 0 & 112 & 68 & \\
\hline & Nagavali-Sarada & 117 & 1 & $56(25)$ & $77(65)$ & \\
\hline & Sarada-Goutami & 63 & 2 & 71 & & \\
\hline & Subtotal & 308 & 5 & 509 & 321 & 835 \\
\hline \multirow[t]{3}{*}{ Central } & Goutami-Veineteya & 25 & 9 & 28 & 122 & \\
\hline & Veineteya-Krishna & 160 & 23 & $259(120)$ & $261(30)$ & \\
\hline & Subtotal & 185 & 32 & 287 & 383 & 702 \\
\hline \multirow[t]{6}{*}{ Southern } & Krishna-Musi & 130 & 5 & & 78 & \\
\hline & Musi-Pennaru & 100 & 20 & & 40 & \\
\hline & Pennaru-Swarnamukhi & 80 & & & 17 & \\
\hline & Swarnamukhi-Pulicat & 50 & & & 20 & \\
\hline & Subtotal & 360 & 39 & $150^{*}$ & 155 & 344 \\
\hline & Total & & 76 & 946 & 859 & 1,881 \\
\hline
\end{tabular}

*Southern Andhra Pradesh was not surveyed in February, and hence nesting from March was used to arrive at a total for the zone. 
Table 4 Nesting between the Rivers Vamsadhara and Nagavali from January to March 2001. The three beaches were separated by the towns Bandarvanipeta and Kunduvanipeta, and represented a stretch of beach south of a river mouth (Vamsadhara to Bandarvanipeta), north of a river mouth (Kunduvanipeta to Nagavali) and the coast in between (Bandarvanipeta to Kunduvanipeta). Beaches were surveyed multiple times during each month and nesting was extrapolated for the entire month from the days surveyed.

\begin{tabular}{|c|c|c|c|c|}
\hline & & Vamsadhara-Bandarvanipeta & Bandarvanipeta-Kunduvanipeta & Kunduvanipeta-Nagavali \\
\hline \multirow{5}{*}{ Jan. } & Name of Beach & Kalingapatnam & Srikakulam & Srikurmam \\
\hline & Length of beach $(\mathrm{km})$ & 5 & 20 & 3 \\
\hline & No. of nests counted & 45 & 10 & 76 \\
\hline & No. of days surveyed & 13 & 6 & 17 \\
\hline & Estimated no. of nests & 107 & 52 & 139 \\
\hline \multirow[t]{3}{*}{ Feb. } & No. of nests counted & 143 & 23 & 91 \\
\hline & No. of days surveyed & 12 & 6 & 23 \\
\hline & Estimated no. of nests & 334 & 107 & 111 \\
\hline \multirow[t]{3}{*}{ Mar. } & No. of nests counted & 50 & 44 & 13 \\
\hline & No. of days surveyed & 12 & 13 & 12 \\
\hline & Estimated no. of nests & 129 & 105 & 34 \\
\hline \multicolumn{2}{|c|}{ Estimated total no. of nests } & 570 & 264 & 283 \\
\hline \multicolumn{2}{|c|}{ Estimated nest density $\left(\mathrm{km}^{-1}\right)$} & 114 & 13 & 94 \\
\hline
\end{tabular}

Table 5 Nesting at four beaches adjacent to river mouths: Kapaskudi, south of Bahuda River in northern Andhara Pradesh; Sacramento, south of Goutami River in central Andhara Pradesh; Krishna River mouth and Sriharikota, north of Pulicat estuary in southern Andhara Pradesh.

\begin{tabular}{|c|c|c|c|c|c|}
\hline & & Kapaskudi & Sacramento & Krishna & Sriharikota \\
\hline Length of beach $(\mathrm{km})$ & & 10 & 10 & 12 & 15 \\
\hline \multirow[t]{3}{*}{ Number of nests } & Jan. & 15 & 36 & 8 & 154 \\
\hline & Feb. & 343 & 241 & 118 & 106 \\
\hline & Mar. & 289 & 331 & 56 & 14 \\
\hline Total nests counted & & 647 & 608 & 182 & 274 \\
\hline Nest density $\left(\mathrm{km}^{-1}\right)$ & & 65 & 61 & 15 & 18 \\
\hline
\end{tabular}

and central Andhra Pradesh, with 22 adjacent beaches suitable for nesting, and nine rivers with 12 adjacent beaches suitable for nesting in southern Andhra Pradesh (Appendix 2). Total nesting was calculated using a conservative value of 50 nests $\mathrm{km}^{-1}$ for northern and central

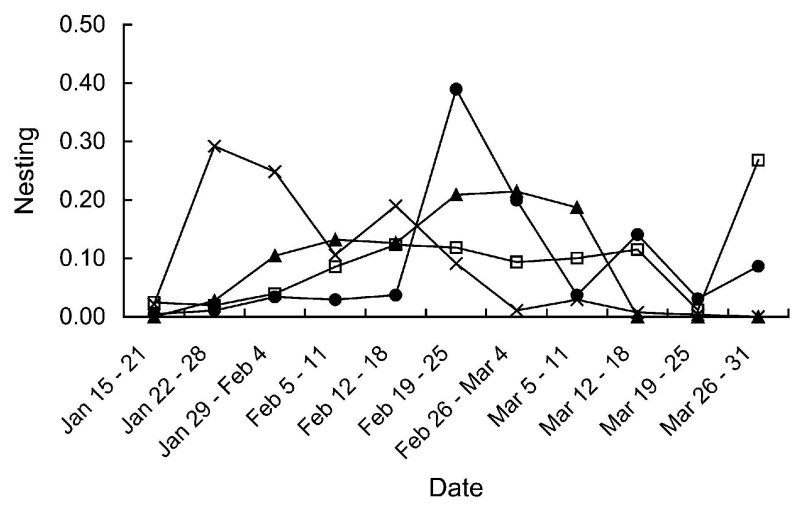

Fig. 2 Weekly nesting of olive ridley turtles at four beaches based on daily surveys, represented as a proportion of total nesting at that beach. The beaches are (a) Kapaskudi (filled circles) (b) Sacramento (crosses) (c) Krishna (filled triangles) (d) Sriharikota (open squares).
Andhra Pradesh (for $18^{*} 3=54 \mathrm{~km}$ ) and 20 nests $\mathrm{km}^{-1}$ for southern Andhra Pradesh (for $12 * 3=36 \mathrm{~km}$ ), giving total potential nesting of c. 3,500 nests at river-mouth beaches along the Andhra Pradesh coast.

For beaches not adjacent to river mouths the extensive survey results indicated that the nesting density in the northern and central zones was twice that of southern Andhra Pradesh. The intensive survey of $20 \mathrm{~km}$ of beach, not adjacent to river mouths and between rivers in northern Andhra Pradesh, gave a nest density of 13 nests $\mathrm{km}^{-1}$. Nest densities were therefore calculated for beaches in northern and central Andhra Pradesh (at 10 nests $\mathrm{km}^{-1}$ over $430 \mathrm{~km}$ ) as 4,300 nests, and for southern Andhra Pradesh (at 5 nests $\mathrm{km}^{-1}$ over $324 \mathrm{~km}$ ) as 1,600 nests, giving a total of 5,900 nests. Combining this with the estimated nesting on beaches adjacent to river mouths gives a total potential nesting for the Andhra Pradesh coast of c. 9,400 nests.

\section{Strandings}

806 dead olive ridley turtles were counted along the Andhra Pradesh coast between November and April 2001. Only five of these were in November and December, but 
172 and 146 were counted during January and February, respectively, along the northern Andhra Pradesh coast alone. The number of dead turtles was less in central and southern Andhra Pradesh. During March and April the mortality declined in all three zones (Fig. 3). Of the 401 dead turtles that were sexed, $105(26.5 \%)$ were males and 296 (73.5\%) were females. Of 111 dead olive ridley turtles measured, seven were $<60 \mathrm{~cm}$ and two were $<50 \mathrm{~cm}$ in curved carapace length, indicating the occurrence of sub-adult turtles in these areas. There was no difference in size between male and female dead turtles, or between dead turtles and turtles captured during offshore trawls (Mann Whitney U test $\mathrm{P}>0.05$; Table 2).

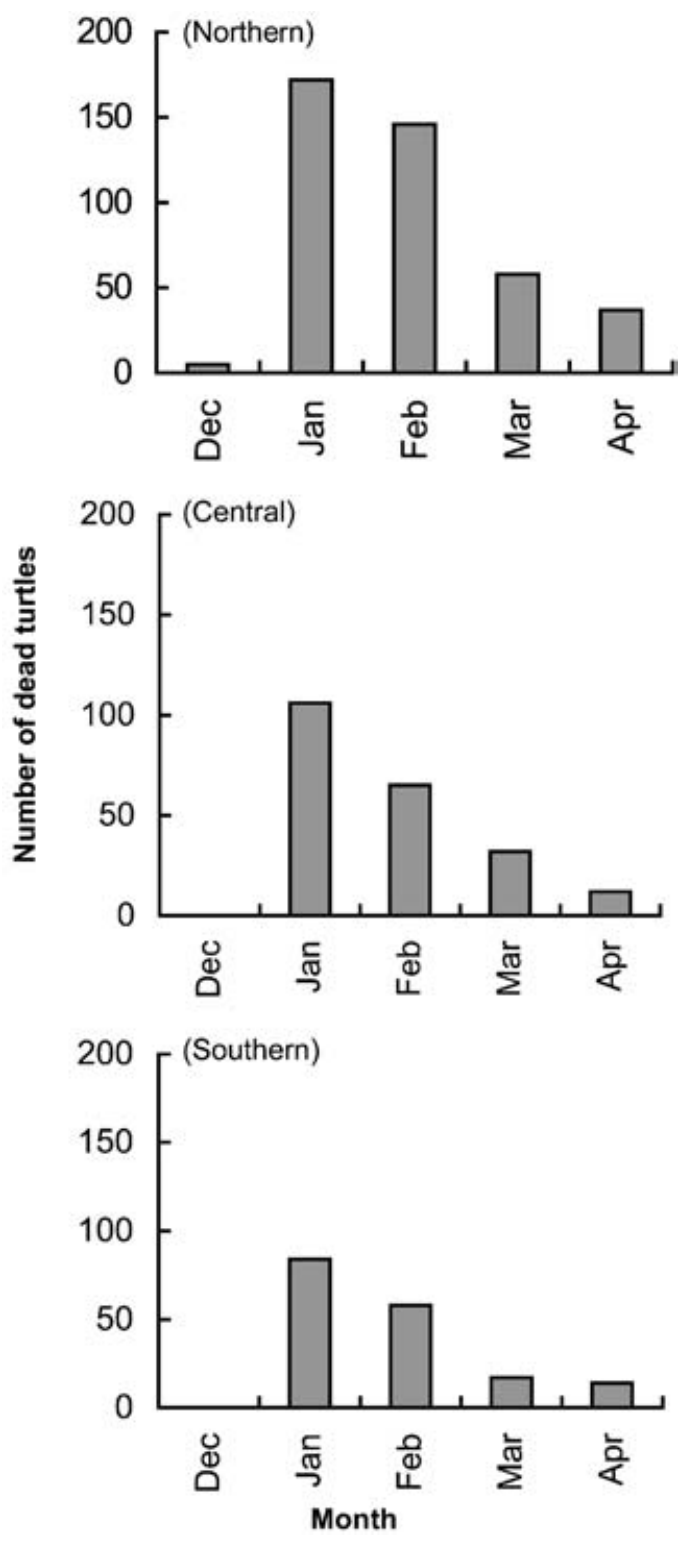

Fig. 3 Monthly tally of dead turtles washed ashore along the three zones of the Andhra Pradesh coast (Fig. 1).

\section{Impact of coastal development along the coast}

Collection of young shrimp was observed all along the coast. Nets are placed parallel to the coastline, and obstruct turtles from nesting. Shrimp hatcheries and prawn farms close to nesting beaches were most abundant along the central Andhra Pradesh coast. These were a major source of disturbance and lighting in this zone.

\section{Discussion}

The abundance of olive ridley turtles at a few sites could give the impression that they are not Endangered, but many sporadic and mass nesting populations of marine turtles may be in decline (Limpus, 1995). In this context a recent response to a petition against the 1996 Red List category of the olive ridley turtle, on the basis that there is evidence of large numbers of nesting turtles and increasing numbers in some areas, ruled that the species should continue to be listed as Endangered (IUCN Red List S\&PS, 2001). Although population trends on the Andhra Pradesh coast could not be evaluated, the surveys described here provide a baseline for future assessments and also indicate potential threats to the population.

The $c .4,000$ nests counted during the survey provide a lower bound for the numbers of olive ridley turtles nesting along this coast. The estimate of a total nesting population of c. 9,500 will need to be revalidated with data on the number of river mouths used for nesting, the length of important nesting beaches, and any variation in nesting between years. However, our data clearly demonstrate that beaches adjacent to river mouths are preferred nesting habitats for olive ridley turtles; these beaches had densities of 50-100 nests $\mathrm{km}^{-1}$ whereas densities averaged c. 10 nests $\mathrm{km}^{-1}$ along other parts of the Andhra Pradesh coast (Tables $3 \& 4$ ) and Tamil Nadu (Shanker, 1995; Bhupathy \& Saravanan, 2002). In Orissa mass nesting beaches are also located in close proximity to river mouths (Pandav, 2001). Whether this preference is due to sediment deposits, salinity or other physiographic features is not known, although it merits investigation. Clearly, however, there is a need to focus conservation and management efforts at specific sites of high turtle density, rather than diffusely along the entire coast.

Olive ridley turtles arrive in Orissa in October and November, when they mate in offshore waters (Pandav, 2001). In both Orissa and Tamil Nadu nesting begins in December and usually peaks after January (Shanker, 1995; Pandav, 2001). In Andhra Pradesh, turtles were sighted in offshore waters during November and December, but nesting was negligible during these months. Nesting occurred during January-March, and was negligible in 
April. This is also supported by information from fishers in Andhra Pradesh, who indicated that the breeding and nesting season occurs between November and March.

Marine turtles occupy a wide variety of habitats from the time they leave their natal beaches; they drift through pelagic habitats as hatchlings, feed in nearshore waters as juveniles, and return to nest as adults. Whereas their behaviour on nesting beaches is relatively well known, the foraging habitats of juvenile marine turtles are poorly documented. Two sub-adult green turtles were found dead near Vishakapatnam, northern Andhra Pradesh (Tripathy \& Choudhury, 2002), and sub-adult olive ridley turtles were captured during experimental trawls and found dead along the Andhra Pradesh coast, suggesting that this coast may also serve as an intermediate developmental habitat for sub-adult ridley turtles and for juvenile and sub-adult green turtles.

The importance of the Andhra Pradesh coast also has to be considered in the context of the large numbers of turtles that nest in Orissa. Genetic studies indicate that all olive ridley turtles along the east coast of India form part of a single large population (Shanker et al., 2000). Olive ridley turtles use multiple nesting sites along the coast of Orissa, separated by up to $300 \mathrm{~km}$ (Pandav, 2001). Beaches used for mass nesting of olive ridley turtles in Orissa are dynamic habitats that may be altered by both human and natural causes (Pandav et al., 1998), and these turtles may be forced to change nesting beach (Shanker et al., 2004). Since the southernmost mass nesting rookery in Orissa is $<50 \mathrm{~km}$ from the Andhra Pradesh border, there is a possibility that turtles from Orissa may also use beaches in Andhra Pradesh. It would therefore be prudent to protect suitable nesting habitats along this coast.

Tagging studies (Pandav, 2001) and satellite telemetry (WII, 2001) show that turtles that nest in Orissa migrate to Sri Lanka after nesting, and there are anecdotal reports of large numbers of turtles migrating together along the east coast of India (Dash \& Kar, 1990). Recent satellite telemetry studies have also shown that olive ridley turtles that nest in Orissa migrate through Andhra Pradesh waters and may even remain in the offshore waters of northern Andhra Pradesh after nesting (WII, 2001). Hence, the turtles that nest in Orissa may face fishery related threats during their migration through Andhra Pradesh waters. The incidental mortality of olive ridley turtles in Orissa may already have caused a serious decline in that population (Shanker et al., in press).

Incidental capture in trawl and gill nets is a major cause of marine turtle mortality along the east coast of India (Rajagopalan et al., 2001) and our study also revealed high levels of fisheries related mortality along the Andhra Pradesh coast. Mortality was higher along the northern coast, which is probably due to the higher density of turtles in that region. Management interventions that would reduce fisheries-related mortality include:

(i) Declaring no-fishing zones during the nesting season in areas where the concentration of marine turtle nesting is high, especially near river mouths.

(ii) Enforcement of existing laws: the Andhra Pradesh Marine Fishing (Regulation) Rules, 1995, state that $<15$ m mechanized vessels may not operate within $8 \mathrm{~km}$ of the coast and vessels $>15 \mathrm{~m}$ in length may not operate within $25 \mathrm{~km}$ of the coast. However, mechanized fishing was observed close to the shore during the present study and clearly the law is not enforced.

(iii) Use of the Turtle Excluder Device: although there is currently substantial opposition within the trawler community to their use in Orissa, the indigenous Turtle Excluder Device developed by the Central Institute of Fisheries Technology, Kochi, is being successfully promoted in Andhra Pradesh by the State Institute of Fisheries Technology, Kakinada (Bavani Sankar \& Ananth Raju, 2003).

The Government of Andhra Pradesh has recently planned a number of new harbours, which are likely to result in an increase in fishing craft, gear and operations, leading to increased fisheries related mortality along the coast. Other problems include pollution from major industries, urban and military sewage, and sand mining. Many of these industries are also sources of light pollution. Casuarina and Palmyra plantations close to the beach render the habitat unsuitable for nesting and provide shelter to egg and hatchling predators, particularly jackals.

It is clear that olive ridley turtles must be protected throughout their nesting and migratory habitats along the east coast of India. However, the State Fisheries Department has only recently initiated measures to curb trawling related mortality (Bavani Sankar \& Ananth Raju, 2003), and none of the nesting beaches or offshore areas are protected by law. The GOI UNDP marine turtle project has conducted preliminary workshops in Andhra Pradesh (Tripathy \& Choudhury, 2001) as well as workshops on coastal development and the relationship between turtles and fisheries, in December 2002. Such workshops serve to increase awareness and participation amongst all stakeholders in marine turtle conservation.

The involvement of state agencies in marine turtle conservation in Andhra Pradesh has so far been minimal, as indicated by interviews with the Forest and Fisheries departments and with fishers, and NGO conservation programmes have focused only on the northern Andhra Pradesh coast (e.g. Ramana Murthy, 2001). During our survey four non-governmental organizations, from all three zones, were invited to assist with data collection and awareness programmes (Tripathy \& Choudhury, 
2001). Their continued involvement will provide a source of data and help with other aspects of turtle conservation such as the inclusion of local communities. In general the traditional fishers are not aware of the legal status of marine turtles, or even of their own fishing rights. Most do not actively fish for turtles and do not have any particular antipathy towards them, and turtles are worshiped along some parts of the coast. Given the high human densities along the coast, it is unlikely that exclusionary protection measures could either be initiated or successfully implemented. In this context it seems most useful to develop programmes based on a participatory approach, rooted in other aspects of coastal conservation and sustainable fishing practices that will also be beneficial to the communities. This would help in protecting multiple nesting habitats and also in protecting the turtles during their breeding migrations through offshore waters. The involvement of these communities and their welfare may thus be critical to the long term survival of marine turtles as well as coastal habitats along this coast.

\section{Acknowledgements}

The Wildlife Institute of India, Dehradun, and Government of India - United Nations Development Programme's Sea turtle project provided funding for this survey. We acknowledge the Andhra Pradesh Forest Department for permits and logistic support and Fishery Survey of India for assistance in offshore surveys. We also thank the Andhra Pradesh Commissioner of Fisheries, National Atlas and Thematic Map Organization, Calcutta, and Survey of India, Dehradun. Several NGOs (AFPRO-Hyderabad, ARDAR-Vizianagaram, Green Mercy-Visakhapatnam, Sravanti-Rajahmundry, CCDPMachilipatnam and SNIRD-Ongole) helped with data collection and provided support during the survey. We are grateful to the fishers and communities along the coast for their generosity and hospitality during the survey. Brendan Godley, Jack Frazier and Bivash Pandav provided reviews and comments that substantially improved the manuscript. K.S. was supported by the Madras Crocodile Bank Trust during the preparation of this manuscript.

\section{References}

Alagaraja, K., Yahannan, K.C., Ammini, P.L. \& Pavitran P.P. (1987) An appraisal of marine fisheries in Andhra Pradesh. Central Marine Fisheries Research Institute Bulletin, 33, 1-52.

Anon. (1999) Hand Book on Fisheries Statistics of Andhra Pradesh. Department of Fisheries, Government of Andhra Pradesh, Hyderabad, India.

Bavani Sankar, O. \& Ananth Raju, M. (2003) Implementation of Turtle Excluder Device in Andhra Pradesh. Kachhapa, 8, 2-5.
Bhupathy, S. \& Saravanan, S. (2002) Status of sea turtles along the Tamil Nadu coast. Kachhapa, 7, 7-13.

Biswas, S. (1982) A report on the olive ridley Lepidochelys olivacea (Eschscholtz) [Testudines: Cheloniidae] of Bay of Bengal. Records of the Zoological Survey of India, 79, 275-302.

Dash, M.C. \& Kar, C.S. (1990) Gahirmatha - The Turtle Paradise. Interprint, New Delhi, India.

Dutt, S. (1976) The leatherback turtle. Sea Food Export Journal, $8,35$.

Dutt, S. (1979) Sea turtle notes from Visakhapatnam. Hamadryad, 4, 14-15.

IUCN (2002) IUCN Red List of Threatened Species. IUCN, Gland, Switzerland [http: / / www.redlist.org, accessed 4 August 2003].

IUCN Red List Standards and Petitions Subcommittee (IUCN Red List S\&PS) (2001) Ruling of the IUCN Red List Standards and Petitions Subcommittee on Petitions Against the 1996 Listing of Four Marine Turtle Species. Http:/ /iucn.org/ themes/ssc/redlists/MarineTurtleDecisions-18-Oct-01.pdf [accessed 14 August 2003].

Kar, C.S. \& Bhaskar, S. (1982) The status of sea turtles in the Eastern Indian Ocean. In Biology and Conservation of Sea Turtles (ed. K.A. Bjorndal), pp. 365-372. Smithsonian Institution Press, Washington, DC, USA.

Kar, C.S. (1983). Notes on marine turtles in Andhra coast, India. Marine Turtle Newsletter, 25, 4-6.

Limpus, C.J. (1995) Global overview of the status of marine turtles: a 1995 viewpoint. In Biology and Conservation of Sea Turtles (ed. K.A. Bjorndal), pp. 605-609. Smithsonian Institution Press, Washington, DC, USA.

Pandav, B. (2001) Conservation and management of olive ridley sea turtles on the Orissa coast. PhD thesis, Utkal University, Bhubaneshwar, India.

Pandav, B., Choudhury, B.C. \& Shanker, K. (1998) The Olive Ridley sea turtle (Lepidochelys olivacea) in Orissa: an urgent call for an intensive and integrated conservation programme. Current Science, 75, 1323-1328.

Pritchard, P.C.H. (1997) Evolution, phylogeny and current status. In The Biology of Sea Turtles (eds P.L. Lutz \& J.A. Musick), pp. 1-56. CRC Press, Boca Raton, USA.

Pritchard, P.C.H. \& Mortimer, J.A. (1999) Taxonomy, external morphology and species identification. In Research and Management Techniques for the Conservation of Sea Turtles (eds K.L. Eckert, K.A. Bjorndal, F.A. Abreu-Grobois \& M. Donnelly), pp. 21-38. IUCN/SSC Marine Turtle Specialist Group Publication No. 4, Washington, DC, USA.

Priyadarshini, K.V.R. (1998) Status and Nesting of Olive Ridley Sea Turtles (Lepidochelys olivacea) along the Northern Andhra Coast. Conservation Corp Volunteer Report, WWF-India, New Delhi, India.

Rajagopalan, M., Vivekanandan, E., Balan, K. \& Narayana Kurup, K. (2001) Threats to sea turtles in India through incidental catch. In Proceedings of the National Workshop for the Development of A National Sea Turtle Conservation Action Plan, Bhubaneshwar (eds K. Shanker \& B.C. Choudhury), pp 12-14. Wildlife Institute of India, Dehradun, India.

Raja Sekhar, P.S. \& Subba Rao, M.V. (1993) Conservation and management of the endangered olive ridley sea turtle Lepidochelys olivacea (Eschscholtz) along the northern Andhra coastline. Testudo, 3, 35-53.

Ramana Murthy, K.V. (2001) Conservation of sea turtles in northern Andhra Pradesh. Kachhapa, 4, 18-19. 
Rao, R.J. (1984) A note on the ridley of Hope Island (Andhra Pradesh, India). Marine Turtle Newsletter, 29, 9-11.

Shanker, K. (1995) Conservation of sea turtles on the Madras coast. Marine Turtle Newsletter, 64, 3-6.

Shanker, K., Aggarwal, R.K., Choudhury, B.C. \& Singh, L. (2000) Conservation Genetics of the Olive Ridley (Lepidochelys Olivacea) on the Orissa Coast. Wildlife Institute of India, Dehradun, India.

Shanker, K., Pandav, B. \& Choudhury, B.C. (2004) An assessment of the olive ridley (Lepidochelys olivacea) nesting population in Orissa, India. Biological Conservation, 115, 149-160.

Subba Rao, M.V., Raja Sekhar, P.S. \& Kameswara Rao, K. (1987) Ecology and Management of Indian Sea turtles. Andhra University, Vishakapatnam, India.

Tambiah, C. (1999) Interview and Market Surveys. In Research and Management Techniques for the Conservation of Sea Turtles (eds K.L. Eckert, K.A. Bjorndal, F.A. Abreu-Grobois \& M. Donnelly), pp. 156-161. IUCN/SSC Marine Turtle Specialist Group Publication No. 4.,Washington, DC, USA.

Tripathy, B. \& Choudhury, B.C. (2001) Sea Turtles and Their Nesting Beaches Along the Andhra Pradesh Coast, India: A Status Survey. Wildlife Institute of India, Dehradun, India.

Tripathy, B. \& Choudhury, B.C. (2002) Recent sighting of the Green turtle Chelonia mydas on the coast of Andhra Pradesh, India. Marine Turtle Newsletter, 98, 3-4.
WII (2001) Satellite tracking of olive ridleys on the Indian coast. Http://www.wii.gov.in/webs/mapaug27.htm [accessed 3 August 2003].

\section{Biographical sketches}

Basudev Tripathy has carried out research on olive ridley turtles in several states in India, including Andhra Pradesh and Orissa. He has recently completed an extensive survey of the sea turtles of the Lakshadweep islands, the first such study in over 20 years.

Kartik Shanker works on various aspects of diversity from the molecular to the organismic level. He is currently interested in the molecular genetics of marine turtles and other herpetofauna, and is the founding editor of Kachhapa, a newsletter concerning the sea turtles of southern Asia.

B. C. Choudhury began working on crocodiles in the mid 1970s, and since then he has initiated conservation projects on other herpetofauna, wetlands and cranes. $\mathrm{He}$ is the coordinator of the Government of India-UNDP sea turtle project. 